\title{
Equal Access to the Vaccination of Covid-19 in Southeast Asia: Can ASEAN be a Catalyst?
}

\author{
Muhammad Insan Tarigan ${ }^{1}$, Raisha Hafandi ${ }^{2}$ \\ ${ }^{1}$ Faculty of Law, Surabaya University, Indonesia. E-mail: insan.tarigan@staff.ubaya.ac.id \\ 2 PT. Insan Cendekia Bina Benua, Indonesia.E-mail: raishahafandi@gmail.com
}

\begin{abstract}
Since the time Covid-19 was discovered in Southeast Asia, around 2.5 million people have been infected and more than 54 thousand have died by early March 2021. Even though ASEAN members have followed most of the WHO recommendations to deal with Covid-19, cases are still liable to increase. Therefore, vaccine utilization is the best chance which people believe in to fight the pandemic for now. However, the vaccine's availability and distribution are a dilemma for the ASEAN member countries. Therefore, this article aims to determine the possibility of ASEAN's role in creating equal access to the Covid-19 vaccine for everyone. According to the juridical normative research, ASEAN is committed to protect and promote human rights and to realize the Sustainable Development Goals (SDGs). On that basis, the organization tends to play an important role in Covid-19 vaccination in Southeast Asia by cooperating with its partners to research and create the required vaccine.
\end{abstract}

Keywords: ASEAN; COVID-19; Southeast Asia; Vaccination

\section{Introduction}

Since the discovery of Covid-19 in late 2019, multiple aspects such as public health, social activity, and the economy have been threatened. Moreover, the disease has spread to 223 countries or different regions since it was declared as a pandemic in March 2020 by WHO. ${ }^{1}$ As of mid-March 2021, more than 119 million people have been infected and over 2.6 million have died. Globally, most of the states introduced new policies and regulations to prevent Covid-19 transmission, for example, the practice of quarantine, physical distancing, travel restrictions, and lockdowns, but ${ }^{2}$ these are not enough effective tools. In Southeast Asia, the first case of Covid-19 was discovered in Thailand on 13th January 2020, and it increases onwards. Until 3rd March 2021, there were around 2.5 million Covid-19 cases in the ASEAN region with more than 54 thousand deaths recorded. ${ }^{3}$ Although some ASEAN member states such as Vietnam, Malaysia, Thailand, and the Philippines implemented national lockdowns with different time ranges to suppress the

\footnotetext{
1 World Health Organization. (2020). WHO Coronavirus (COVID-19) Dashboard, Available Online from: https://www.who.int/emergencies/diseases/novel-coronavirus-2019. [Accessed, March 15, 2021]

2 Forman, L., \& Kohler, J. C. (2020). Global health and human rights in the time of COVID-19: Response, restrictions, and legitimacy. Journal of Human Rights, 19(5), 547-556. https://doi.org/10.1080/14754835.2020.1818556.

${ }^{3}$ ASEAN Biodaspora Virtual Center. (2021). Risk Assessment for International Dissemination of COVID-19 to the ASEAN Region (Vol. 2021). https://asean.org/storage/COVID-19 Report-of-ASEAN-BioDiaspora-Regional-VirtualCenter 26February2021.pdf. [Accessed March 15, 2021.]
} 
disease's spread. Meanwhile, Indonesia preferred Large Scale Social Restriction (PSBB) policy to the national lockdown. ${ }^{4}$ The ASEAN members have also followed WHO recommendations in handling Covid-19, for instance, social and physical distancing, wearing a mask, rapid testing, contact tracing, and quarantine for suspected cases. These measures were proven to be insufficient in stopping the spread, therefore the best and safest vaccine is believed as the only hope to combat Covid-19.

At the end of 2020, the mass-produced Covid-19 vaccine in United States, Russia, and China has already been distributed globally. Provided that vaccine development is a good chance in resisting this pandemic, yet the distribution is a significant problem that must be faced. Without global and coordinated efforts to ensure the vaccine is accessible for every person, priority access becomes a concern as it tends to be defined according to pay ability, nationality, and residence state, besides evidence-based needs. ${ }^{5}$ Hence, the distribution process creates a dilemma for all authorities in the world, both within and inter-states. The state government is under pressure to obtain the effective and safe vaccine rapidly to meet its people's needs, which is liable to cause the disrepair of other citizens' health. Contrarily, the pandemic is a global phenomenon that has affected almost everyone. For effectiveness and international law, the state government needs to respect other citizens' health. ${ }^{6}$ As the main entity in international law, international organizations either at the universal or regional level, need to participate in confirming the fairness of vaccine distribution.

Specifically in Southeast Asia, can ASEAN play a role in encouraging solidarity among states and agree to guarantee equal access towards the safe and effective vaccine? The Economist Intelligence Unit (EIU) estimated diverse time is needed to attain a comprehensive vaccination. Singapore is predicted to achieve this purpose in early 2022, while Myanmar, Laos, Cambodia, the Philippines, and Indonesia tend to require at least 4 years. $^{7}$ The ASEAN has to function in ensuring an equal vaccine distribution as it is in line with a collective effort of the member states encouraging the organization which is inclusive, people-centered, and with no one left behind. Hence, the attainment of the Sustainable Development Goals (SDGs) is facilitated. ${ }^{8}$

Several articles examine the aforementioned disease, one of which is connecting Covid19 with the evolution that tends to occur to human rights specifically in the health aspect. ${ }^{9}$ Human rights implementation to manifest access to the required vaccine

\footnotetext{
${ }^{4}$ Rahayu, S., \& Sulistiadi, W. (2020). The Effectiveness of COVID-19 Countermeasure Policy Implementation in Seven ASEAN Countries. Journal of Indonesian Health Policy and Administration, 5(2), 43-49. https://doi.org/10.7454/ihpa.v5i2.3880.

${ }^{5}$ United Nations Human Rights. (2020). Human Rights and Access to Covid-19 Vaccines. In Human Rights at The Heart of Response. Nomos Verlagsgesellschaft mbH \& Co. KG. https://doi.org/10.5771/9783845273945.

${ }^{6}$ Bogdandy, A. von and P. A. V. (2020). The Role of International Law in Vaccinating Against Covid-19: Appraising the Covax Initiative (No. 2020-46; MPIL Research Paper Series).

7 Strangio, Sebastian. (2021). Southeast Asia COVID-19 Vaccine Coverage a Long Way Off: Report, Available Online from: $\quad$ https://thediplomat.com/2021/01/southeast-asia-covid-19-vaccine-coverage-a-long-way-off-report/. [Accessed March 20, 2021]

8 Zen, F., Komazawa, O., Gross, J., Menon, J., Zen, F., Komazawa, O., \& Gross, J. (2019). Leave No One Behind. In Kimura, F., V. Anbumozhi, H. Nishimura. (eds.). Transforming and Deepening the ASEAN Community (Issue May, pp. 147-162). Jakarta: ERIA.

${ }^{9}$ Forman, L., \& Kohler, J. C. (2020). Global health and human rights in the time of COVID-19: Response, restrictions, and legitimacy. Journal of Human Rights, 19(5), 547-556. https://doi.org/10.1080/14754835.2020.1818556.
} 
predicted the development of new global governance through the law is needed. ${ }^{10}$ ASEAN members' responses toward the disease have been discussed by other sources. Based on media the statement and policy research from each of the ASEAN members, this organization is believed to have a constructive role in formulating a response towards the coordinated pandemic. ${ }^{11}$ The comparative national policy on handling Covid-19 provided by states in Southeast Asia has shown a new perspective of maintaining the relationship between government and citizens to implement the most effective policy for reducing the death rate. ${ }^{12}$ This article focuses on the possibility of ASEAN's role in creating equal access to Covid-19 vaccination in Southeast Asia. It is reviewed from ASEAN's role as an international organization, namely commitment towards the fulfillment of human rights and SDGs.

\section{Method}

A juridical normative research method was used, which is based on the positive law and it is also relevant to ASEAN's role in fulfilling human rights. Analysis was conducted using the descriptive method which explains human rights' principles fulfillment through vaccination by the international organization, to achieve SDGs target, specifically on health and welfare strength or SDGs-3. This article used a legal approach that emphasizes more on international law, either soft or hard. Data were collected from kinds of literature, to obtain relevant law instruments along with secondary research sources, such as books, national or international journals, and more, then analyzed qualitatively.

\section{Human Rights and SDGs Call for Covid-19 Vaccines.}

\subsection{Covid-19 Vaccines in the Human Rights Context}

Commitments to propose and protect human rights, as well as respect fundamental freedoms universally from states around the world are already mentioned in Articles 1 and 3 of the United Nations (UN) Charter. These were followed up by United Nations through 2 (two) mechanisms. Firstly, the United Nations human rights system has a treaty body created by its Charter, one of which is the Human Rights Council. This is known as the United Nations Charter-based Mechanism. Secondly, another one known as the Treaty-based system covers international agreements concerning human rights agreed among states, such as the Universal Declaration on Human Rights (UDHR) and International Bill of Rights, etc. ${ }^{13}$ UN treaty bodies and Charter-based the mechanism

\footnotetext{
10 Gostin, L. O., Karim, S. A., \& Mason Meier, B. (2020). Facilitating Access to a COVID-19 Vaccine through Global Health Law. Journal of Law, Medicine and Ethics, 48(3), 622-626. https://doi.org/10.1177/1073110520958892.

${ }_{11}$ Djalante, R., Nurhidayah, L., Minh, H. Van, Thi, N., Phuong, N., Mahendradhata, Y., Trias, A., Lassa, J., \& Ann, M. (2020). COVID-19 and ASEAN responses: Comparative policy analysis. Progress in Disaster Science, 8(January), 1-12. https://doi.org/http://dx.doi.org/10.1016/j.pdisas.2020.100129.

12 Rahayu, S., \& Sulistiadi, W. (2020). The Effectiveness of COVID-19 Countermeasure Policy Implementation in Seven ASEAN Countries. Journal of Indonesian Health Policy and Administration, 5(2), 43-49. https://doi.org/10.7454/ihpa.v5i2.3880.

${ }^{13}$ Kaufman, R. E. (2011). Using Human Rights Mechanisms of the United Nations to Advance Economic Justice. Journal of Poverty Law and Policy, 1(6), 259-267.
} 
provide every individual with various possibilities to claim for government and institution protection on the international level.

Amidst the Covid-19 pandemic, the rights to life become a concern for every action performed by the states related to fighting the disease. Article 6 of the International Covenant on Civil and Political Rights (ICCPR) become the basis emergence of state obligation towards human rights. Therefore, states need to carry out the right action and maximize all resources to resolve Covid-19 to protect many lives and fulfill the right to health, ${ }^{14}$ since the disease is recognized as a global public health threat impacting negatively to the quality of humanity as known.

Fundamental rights of health and social protection are recognized internationally and also stated in Article 25 UDHR. In line with the declaration of WHO in 1946, the enjoyment of the highest attainable health standard is one of the fundamental human rights without distinction of race, religion, political belief, and economic or social condition. ${ }^{15}$ Moreover, Article 12 paragraph 1 of Covenant on Economic, Social, and Cultural Rights (ICESCR) emphasizes that states' parties need to recognize everyone's right to the enjoyment of the highest attainable physical and mental health standard.

Article 12 paragraph 2, point c ICECSR stated that states parties need to take a certain step to achieve the full realization of the right to health as well as the prevention, treatment, and control of epidemic, endemic, occupational, and other diseases. Human Rights Council gives some annotations concerning the Rights to the Highest Attainable Health Standard, which is called comment 14 , namely: ${ }^{16}$

a) To ensure reproductive, maternal (prenatal as well as post-natal), and child health care;

b) To provide immunization against the major infectious diseases occurring in the community;

c) To take measures to prevent, treat, and control epidemic and endemic diseases;

d) To provide education and access to information concerning the main health problems in the community, including methods of preventing and controlling them;

e) To provide appropriate training for health personnel, including education on health and human rights.

Measures such as mask utilization and lockdown were already implemented by states to prevent the spread of Covid-19, but they have been ineffective. Therefore, the most dependable resistance to the disease is a vaccine. The availability of a safe, effective, accessible, and free vaccine for everyone is needed to end this pandemic, ${ }^{17}$ which tends to save lots of life in line with the fundamental human rights to life. Scientifically, immunization is the best preventive tool and the most important element for the right to

\footnotetext{
14 Saunders, J. (2020). Covid-19 and Human Rights. Oxfam Discussion Paper. 1 - 48.

15 Institute for Human Rights and Business. (2020). Respecting Human Rights in the Time of the COVID-19 Pandemic: Examining Companies' Responsibilities for Workers and Affected Communities. Available Online at https://www.ihrb.org/focus-areas/covid-19/report-respecting-.

16 Saunders, J. (2020). Covid-19 and Human Rights. Oxfam Discussion Paper. 1 - 48.

17 Oxfam Discussion Paper. $1-48$.
} 
the Highest Attainable Health Standard ${ }^{18}$ as already stated above in the General Comment of the Human Rights Council 14, point b.

The Covid-19 vaccine is supposed to be considered as a global public good, besides a commodity that is traded in the market. ${ }^{19}$ Therefore, its accessibility need not be based on someone or richer states' purchase ability in the decrement of the poorest. This vaccine is a form of human rights fulfillment obtaining benefits from scientific progress, which has become the state's obligation to ensure the scientific progress is felt by everybody. ${ }^{20}$ The United Nations Special Rapporteur concerning the right to health concluded that state is mandatory to "do all they reasonably can to make sure that existing medicines are available in sufficient quantities". ${ }^{21}$ For the sake of health fulfillment rights, states have an important role to immediately and effectively accomplish universal access to vaccines.

Covid-19 vaccine tends to be considered in relation with human rights perspective, once the availability of safe and effective vaccine is provided by the states with the following conditions: ${ }^{22}$

1. Available: The produced vaccine is widely and sufficiently distributed by states.

2. Accessible: States need to eliminate obstacles to the process of vaccine distribution for vulnerable and marginalized populations, make sure the vaccine is affordable, in good condition, and equipped with all the information that is needed.

3. Acceptable: The vaccination process needs to be performed with the individual's consent and adjusted with the society's tradition.

Of Sufficient Quality: The vaccine needs to fulfill the requirement of being "scientifically and medically appropriate and of good quality", to avoid fake vaccines, inadequate and ingenious health workers, and approved equipment.

Non-discrimination principles need to be implemented by states as a form of paying attention to the vulnerable society. Also, the Covid-19 vaccine needs to reach the vulnerable categories such as women, indigenous people, beggars, LGBTQ groups, people with disabilities, and immigrants - especially stateless immigrants, minority society, and other marginalized groups. ${ }^{23}$ Article 1 of DUHAM stated that: "All human beings are born free and equal in dignity and rights". The vaccine's benefit tends to be effective when it is equally accessible for all states. A big risk is faced when there is one state or region that still lacks the Covid-19 vaccine. Therefore, those unable to conduct vaccination need to

\footnotetext{
18 Gostin, L. O., Karim, S. A., \& Mason Meier, B. (2020). Facilitating Access to a COVID-19 Vaccine through Global Health Law. Journal of Law, Medicine and Ethics, 48(3), 622-626. https://doi.org/10.1177/1073110520958892.

19 United Nations Human Rights. (2020). Human Rights and Access to Covid-19 Vaccines. In Human Rights at The Heart of Response. Nomos Verlagsgesellschaft mbH \& Co. KG. https://doi.org/10.5771/9783845273945.

20 Committee on Economic Social and Cultural Rights (CESCR), General Comment No. 25 (2020) on science and economic, social and cultural rights (article 15 (1) (b), (2), (3) and (4) of the Covenant), para. 70.

21 Gostin, L. O., Karim, S. A., \& Mason Meier, B. (2020). Facilitating Access to a COVID-19 Vaccine through Global Health Law. Journal of Law, Medicine and Ethics, 48(3), 622-626. https://doi.org/10.1177/1073110520958892.

22 Gostin, L. O., Karim, S. A., \& Mason Meier, B. (2020). Facilitating Access to a COVID-19 Vaccine through Global Health Law. Journal of Law, Medicine and Ethics, 48(3), 622-626. https://doi.org/10.1177/1073110520958892.

${ }^{23}$ Nigam, Shalu. (2021). Ensuring Vaccine Equity, Erasing Vaccine Nationalism: Upholding the Human Rights and Justice Framework (April 15, 2021). Available at SSRN: https://ssrn.com/abstract $=3827273$ or http://dx.doi.org/10.2139/ssrn.3827273.
} 
obtain assistance from international entities as both developing and developed states are required to provide the vaccine. ${ }^{24}$

The Covid-19 Vaccines Global Access (COVAX) mechanism, a product of partnership, is global cooperation to advance vaccine development and production, including attaining equitable distribution. ${ }^{25}$ In addition to ensuring provision to all countries, COVAX also aims to prepare vaccines at low prices. High-income countries buy vaccines from COVAX at an estimated average price of $\$ 11$ per dose, while it is available at about $\$ 1.6-2.0$ per dose for the low- and middle-income ones. ${ }^{26}$ In addition, several regional mechanisms have been presented, such as the Covid-19 African Vaccine Acquisition Task Team (AVATT) to support the African Vaccine Strategy and the Asia-Pacific Vaccine Access Facility. ${ }^{27}$ Although some progress is being made through COVAX and the direct distribution of overdosing vaccines between countries, efficient and equitable distribution globally cannot simply depend on donors' goodwill and temporary solutions. ${ }^{28}$ Therefore, developing countries' governments urgently need to develop and produce sustainable long-term vaccines.

Moreover, Covid-19 vaccination needs to be held transparently. ${ }^{29}$ Any kinds of information regarding production, ingredients, side effect and vaccine procurement budget have to be generally known. Such clear information helps society to respond to the government's policy concerning vaccination programs. Article 19 Para (2) of ICCPR specifies that every individual shall have the right to freedom of expression; this right shall include freedom to seek, receive and impart information and ideas of all kinds, regardless of frontiers, either orally, in writing, or print, in the form of art, or through any media of his choice.

The effective Covid-19 vaccine needs to be considered as a global public good, ${ }^{30}$ and all states ought to benefit from global cooperation. In an abnormal situation, any kind of state or company need not obtain an advantage from the circumstances. Hence, global governance is needed to ensure the Covid-19 vaccine is widely accessible and

\footnotetext{
24 Nigam, Shalu. (2021). Ensuring Vaccine Equity, Erasing Vaccine Nationalism: Upholding the Human Rights and Justice Framework (April 15, 2021). Available at SSRN: https://ssrn.com/abstract=3827273 or http://dx.doi.org/10.2139/ssrn.3827273.

${ }^{25}$ Terzakis, K., \& Maren Klein. (2021). SDG 17: Partnerships for the Goals. Policy Brief. 1 - 8.

26 Wouters, O. J., Shadlen, K. C., Salcher-konrad, M., Pollard, A. J., Larson, H. J., Teerawattananon, Y., \& Jit, M. (2021). Health Policy Challenges in ensuring global access to COVID-19 vaccines: production, affordability, allocation, and deployment. The Lancet, 397(10278), 1023-1034. https://doi.org/10.1016/S0140-6736(21)00306-8.

27 OECD. (2021). Coronavirus (COVID-19) vaccines for developing countries: An equal shot at recovery. In OECD Policy Responses to Coronavirus (Issue February). https://www.oecd.org/coronavirus/policy-responses/coronaviruscovid-19-vaccines-for-developing-countries-an-equal-shot-at-recovery-6b0771e6/\#blocknotes-d7e2077.

28 OECD. (2021). Access to COVID-19 vaccines: Global approaches in a global crisis. In OECD Policy Responses to Coronavirus (Issue March). https://www.oecd.org/coronavirus/policy-responses/access-to-covid-19-vaccines-globalapproaches-in-a-global-crisis-c6a18370/.

${ }^{29}$ Human Rights Watch. (2020). "Whoever Finds the Vaccine Must Share It" Strengthening Human Rights and Transparency around Covid-19 Vaccines. Report, (October 2020). https://www.hrw.org/sites/default/files/media 2020/10/globalvaccine1020 web.pdf.

30 Nigam, Shalu. (2021). Ensuring Vaccine Equity, Erasing Vaccine Nationalism: Upholding the Human Rights and Justice Framework (April 15, 2021). Available at SSRN: https://ssrn.com/abstract=3827273 or http://dx.doi.org/10.2139/ssrn.3827273.
} 
affordable. ${ }^{31}$ For affordability's sake, increasing the capacity of low- and middle-income countries (LMIC) is necessary to produce vaccines. However, intellectual property rights (IPR) hampers vaccine access to LMICs. The new medicines are protected by patent law, so it restricts LMIC from producing the same vaccines. Intellectual Property Rights (IPR) provides exclusive rights for contriver, to facilitate the potential for monopoly. ${ }^{32}$

International law governs the protection of patent universally, through the Paris Convention for the Protection of Industrial Property of 1883 and the Agreement on Trade-Related Aspects of Intellectual Property Rights (TRIPS), which also lies under the WTO Marrakech Accords. ${ }^{33}$ Article 27 para (1) states patents shall be available for any inventions, whether products or processes, in all fields of technology, provided that they are new, involve an inventive step, and are capable of industrial application. Being aware that patents tend to be an obstacle in realizing affordable access to Covid-19 health products, WHO and partners launched the Covid-19 Technology Access Pool (C-TAP) in May 2020. C-TAP is a potential center for global developers of health products for this disease, including vaccines to share their intellectual property rights, knowledge, and data and as well join the Solidarity all to Action. By this voluntary agreement, Covid-19 Vaccine's developers increase production through multiple manufacturers with nonexclusive and transparent licenses. ${ }^{34}$ In this early stage of vaccination, international solidarity becomes an expectation both for low- and middle-income countries to access the Covid-19 vaccine.

\subsection{Covid-19: New Guest in the Way to Realize the SDGs}

The 2030 agenda which is known as "Sustainable Development Goals (SDGs)" ratified in September 2015 by 193 United Nations member states after a prolonged negotiation among the governments for 3 (three) years since it was agreed in the UN Conference on Sustainable Development or Rio +20 in Rio de Janeiro, in June 2012. ${ }^{35}$ The 2030 Agenda for Sustainable Development offers a blueprint for prosperity and peace for the world and humans for now and the future. The accomplishment of this agenda tends to be determined by an achievement of 17 SDGs, which needs action from all states within the framework of a global partnership. United Nations' members understand that to end poverty and other deprivations, they must go conjointly with a strategy that tends to improve health and education, reduce inequality, and encourage economic growth, while

${ }^{31}$ Gostin, L. O., Karim, S. A., \& Mason Meier, B. (2020). Facilitating Access to a COVID-19 Vaccine through Global Health Law. Journal of Law, Medicine and Ethics, 48(3), 622-626. https://doi.org/10.1177/1073110520958892.

32 Bogdandy, A. von and P. A. V. (2020). The Role of International Law in Vaccinating Against Covid-19: Appraising the Covax Initiative (No. 2020-46; MPIL Research Paper Series).

33 World Health Organization, World Trade Organization and World Intellectual Property Organization. (2020). Promoting Access to Medical Technologies and Innovation (2nd ed.). WHO, WTO and WIPO. https://doi.org/10.30875/fa323700-en.

34 World Health Organization. (2020). WHO Covid-19 Technology Access Pool. https://www.who.int/initiatives/covid-19-technology-access-pool. [Accessed June 13, 2021]

${ }^{35}$ Mukarram, M. (2020). Impact of COVID-19 on the UN Sustainable Development Goals (SDGs). Strategic Analysis, 44(3), 253-258. https://doi.org/10.1080/09700161.2020.1788363. 
overcoming climate change along with preserving the sea and forest. ${ }^{36}$ Here are the already agreed 17 goals: ${ }^{37}$

1. SDG 1 : No Poverty

2. SDG 2 : Zero Hunger

3. SDG 3 : Good Health and Well-being

4. SDG 4 : Quality Education

5. SDG 5 : Gender Equality

6. SDG 6 : Clear Water and Sanitation

7. SDG 7 : Affordable and Clean Energy

8. SDG 8 : Decent Work and Economic Growth

9. SDG 9 : Industry, Innovation, and Infrastructure

10. SDG 10: Reduce Inequality

11. SDG 11: Sustainable Cities and Communities

12. SDG 12: Responsible Consumption and Production

13. SDG 13: Climate Action

14. SDG 14: Life Below Water

15. SDG 15: Life on Land

16. SDG 16: Peace, Justice and Strong Institutions

17. SDG 17: Partnerships to Achieve the Goals

The achievement of these goals is affected by Covid-19 which is a global challenge, but each state has a different impact depending on the social-economic condition. Moreover, developing and small island states face some hardship. United Nations Department of Economic and Social Affairs predicted global remittent has decreased the cause of Covid19. Moreover, poor people are suffering because of this pandemic. In monetary terms, low- and middle-income states are experiencing a loss of $\$ 445$ million. ${ }^{38}$ There are lots of acknowledgments that the disease is attacking those living with poverty.

The pandemic has caused an immediate impact on the 17 SDG goals as mentioned above. One of them is SDG-1, namely "no poverty," which is the most basic and most important thing in the SDGs ${ }^{39}$, however, Covid-19 has huge potential in increasing poverty universally at a rate of 420-580 million people, because the current economic stagnation is unavoidable. This is possibly the first escalation in global poverty since $1990 .{ }^{40}$ Covid19 has caused about 18 million ASEAN's people to become poor, inclusive of 3 million in

36 United Nations. (2015). The 17 Goals. Available Online from: https://sdgs.un.org/goals. [Accessed March 22, 2021]

United Nations. (2015). Take Action for the Sustainable Development Goals. https://www.un.org/sustainabledevelopment/sustainable-development-goals/. [Accessed March 25, 2021]

${ }^{38}$ Terzakis, K., \& Maren Klein. (2021). SDG 17: Parnerships for the Goals. Policy Brief. 1 - 8.

39 UNDP. (2020). Impact of COVID-19 on the Sustainable Development Goals: Pursuing the SDGs in a World Reshaped by COVID-19. https://sdgintegration.undp.org/sites/default/files/Impact_of_COVID-19_on_the_SDGs.pdf.

${ }^{40}$ Sumner, A., Hoy, C., \& Ortiz-Juarez, E. (2020). Estimates of the impact of COVID-19 on global poverty. UNU WIDER Working Paper 2020/43, April 1-9. https://doi.org/10.35188/UNU-WIDER/2020/800-9. 
extreme poverty ${ }^{41}$ which is the main reason for hunger in the world and it is counterproductive to the second priority in SDGs (SDG-2).

An effort to promote sustained, inclusive, and sustainable economic growth, full and productive employment, and decent work on SDG-8 in 2030 is liable to also face some obstacles. Foreign Direct Investment (FDI) fell by 40\% in 2020, and the FDI flows in 2021 is expected to decrease by a further $5-10 \%{ }^{42}$. Even though, foreign investment ought to build resilient infrastructure, promote inclusive and sustainable industrialization, and foster innovation globally (SDG-9). Based on such data, it is estimated that 285 million people or around $80 \%$ from 4 (four) African states (Ethiopia, Malawi, Nigeria, and Uganda) have lost their livelihood because of Covid-19. ${ }^{43}$ This disease has also paralyzed the ASEAN economy through the following factors: firstly, lower global demand has decreased the organization's exports. Secondly, the reduction of foreign direct investment (FDI) in the ASEAN region, and finally, the downturn in the number of foreign tourists to ASEAN is very drastic. Covid-19 has rendered over 30 million people in ASEAN unemployed, ${ }^{44}$ thereby indicating its immediate impact on reducing inequality within and among countries (SDG-10).

With that regard, the vaccine has become the main protection ${ }^{45}$ and a tool in stopping adverse effects of COVID-19 in all aspects especially to the SDGs. One of the most costeffective health-care to save lives and improve health and prosperity [SDGs] is through vaccinations. Annual vaccines save up to 2-3 million lives yearly and prevent countless disease cases. ${ }^{46}$ The accomplishment of vaccinations depends on accessibility as well as affordability. ${ }^{47}$

An important factor capable of making vaccines accessible and affordable for all is a partnership. Hence, the Covid-19 vaccine should be produced based on SDGs principles that are "leaving no one behind" and "multi-stakeholder partnerships". Participation from government, international organizations, corporations, societies, and individuals is needed to create the vaccines [SDG-14]. A holistic approach needs to be stressed to stop the current pandemic.

41 Ing, Lili Yan. (2021). "Economic outlook 2021: Beware of prolonged recession". Click to read: https://www.thejakartapost.com/academia/2021/01/05/economic-outlook-2021-beware-of-prolongedrecession.html., [Accessed June 5, 2021]

42 Terzakis, K., \& Maren Klein. (2021). SDG 17: Parnerships for the Goals. Policy Brief. $1-8$.

43 Kilic T, Michler J. (2020). Socio-Economic Impacts of COVID-19 in Four African Countries: Watch the Event Recording. Available at: https://www.worldbank.org/en/programs/Isms/brief/socioeconomic-impacts-of-covid-19-infour-african-countries-watch-the-event-recording. [Accessed March 19, 2021]

44 Ing, Lili Yan. (2021). "Economic outlook 2021: Beware of prolonged recession". Click to read: https://www.thejakartapost.com/academia/2021/01/05/economic-outlook-2021-beware-of-prolongedrecession.html., [Accessed June 5, 2021].

45 Seshaiyer, P., \& McNeely, C. L. (2020). Challenges and Opportunities From COVID-19 for Global Sustainable Development. World Medical and Health Policy, 12(4), 443-453. https://doi.org/10.1002/wmh3.380.

46 Gavi. (2020). "Sustainable Development Goals". Available Online from: https://www.gavi.org/ouralliance/global-health-development/sustainable-development-goals. [Accessed March 26, 2021]

47 Seshaiyer, P., \& McNeely, C. L. (2020). Challenges and Opportunities From COVID-19 for Global Sustainable Development. World Medical and Health Policy, 12(4), 443-453. https://doi.org/10.1002/wmh3.380. 


\section{ASEAN for Equal Access to the Covid-19 Vaccines in Southeast Asia}

Viruses such as SARS-COV-2 are the commonest biological entities on Earth, and they are transmitted from one person to another. Therefore, Covid-19 vaccine development and distribution need to be performed with good coordination. The most effective, sustainable, and decent response to overcome this global crisis is by also producing the vaccine based on all states' solidarity. Furthermore, data and technology need to be transferred among states, international organizations, the private sector, and the government to support the campaign for a successful and inclusive global vaccination. ${ }^{48}$ To further support this activity, global cooperation is required to create an effective vaccination that is beneficial to all nations. ${ }^{49}$ In Southeast Asia, ASEAN is expected to realize general access to the vaccine.

The ASEAN has a high commitment concerning the promotion and attainment of SDGs, as well as human rights protection. At least those 2 indicators are enough to promote this organization's function in ensuring vaccination is available for all societies in Southeast Asia. SDGs in the context of national development are already adopted by all ASEAN members which are fully committed to support and implement the 2030 Agenda and SDGs as part of efforts to stop poverty, inequity, and injustice. The ASEAN charter's preamble confirmed that this organization is committed to ensuring "sustainable development for the benefit of the present and future generations and to place the peoples' well-being, livelihood, and welfare at the centre of ASEAN community building process". ${ }^{50}$ This commitment is difficult to fulfil because Covid-19 has constrained its progress through stagnancy or reversal of the developmental process. Consequently, once ASEAN wants to resume work on achieving SDGs, the disease needs to be stopped immediately, which tends to occur only when fair vaccination is implemented.

The Covid-19 pandemic has a negative impact on the efforts targeted at fulfilling human rights in Southeast Asia. This includes initiating a right to health crisis, therefore human rights need to be positioned as a core focus or the basis of government response to the disease. ${ }^{51}$ The journey on countermeasures to be used still requires lots of works and casualties, not only in the ASEAN region but also globally. Continuous cooperation among different states is needed to protect everyone's rights in this pandemic. The longer the crisis exists, the more human rights are restricted. Recently, vaccination is the biggest hope in stopping the spread of Covid-19.

Covid-19 vaccination in Southeast Asia needs to be conducted based on nondiscrimination principles. Every individual is entitled to the benefit of the proposed vaccine, in line with article 9 paragraph 1 of the ASEAN Human Rights Declaration (AHRD), which states "every person has the right to enjoy the highest attainable standard of physical, mental and reproductive health, as well as basic and affordable health care

\footnotetext{
48 United Nations Human Rights. (2020). Human Rights and Access to Covid-19 Vaccines. In Human Rights at The Heart of Response. Nomos Verlagsgesellschaft mbH \& Co. KG. https://doi.org/10.5771/9783845273945.

49 Moon, S., Rottingen, J. A., \& Frenk, J. (2017). Global public goods for health: Weaknesses and opportunities in the global health system. Health Economics, Policy and Law, 12(2), 195-205. https://doi.org/10.1017/S1744133116000451

50 Secretary-general of ASEAN. (2007). The ASEAN Charter. Jakarta: ASEAN Secretariat.

51 FORUM-ASIA. (2020). Human Rights in Southeast Asia in Times of Pandemic. Available at https://humanrightsinasean.info/wp-content/uploads/2020/09/LO-CovidASIAF3.pdf.
} 
services, and obtain access to medical facilities". This is why the organization needs to ensure that "no Southeast Asian country is left behind" on the vaccination. The problem encountered is that currently Covid-19 vaccine is not produced independently by the member states.

The ASEAN has solid regional cooperation as confirmed in the preamble of its Charter. The member states already have a strong core to corporate and combat Covid-19 together. Besides, the regional corporation has the potential to obtain support from partners such as ASEAN plus one and ASEAN plus Three. On 14th April 2020, In Vietnam, ASEAN leaders, along with President Xi Jinping, Prime Minister Shinzo Abe, and President Moon Jae-in met in the Special ASEAN Summit and ${ }^{52}$ the result was to act jointly and decisively to control the spread of Covid-19. They also agreed to strengthen public health cooperation and joint research regarding vaccine and anti-viral medicines, as well as to intensify public communication and reduce stigmatization and discrimination and create the required Covid-19 ASEAN Response Fund. ${ }^{53}$

The international law obliges states to achieve the progressive realization of the rights protected by the Covenant, which includes the right to health. ${ }^{54}$ The WHO International Health Regulations also requires states "to collaborate, to any possible extent, in: (1) the detection and assessment of and response to events as provided. (2) The provision or facilitation of technical cooperation and logistical support, particularly in the development, strengthening and maintenance of the required public health capacities. (3) The mobilization of financial resources to facilitate their obligations' implementation, and (4) the formulation of proposed laws and other legal and administrative provisions for the Regulations' implementation." 55 ASEAN member states are also committed to enhancing partnerships for sustainable development through SDGs-17. Therefore, the best means for the organization to ensure equitable access to Covid-19 vaccines is through international cooperation and assistance, because international cooperation both globally and regionally is a key requirement for this purpose.

A regional approach is required within the ASEAN framework, considering that COVAX has not yet provided the Covid-19 vaccine to low- and middle-income countries because the stocks are determined by donations from developed countries. The highest-income countries control $80 \%$ of the world's vaccines while the low-income ones only access $10 \% .{ }^{56}$ Therefore, the ASEAN members cannot only rely on donations or vaccines obtained at low prices through the COVAX scheme. But, the organization urgently needs to produce its vaccines with international assistance in some form, such as by technology transfer and sharing of knowledge and vaccine recipe.

\footnotetext{
52 ASEAN. (2020). Declaration of the Special ASEAN Summit on Coronavirus Disease 2019 (COVID-19). Available at https://asean.org/storage/2020/04/FINAL-Declaration-of-the-Special-ASEAN-Summit-on-COVID-19.pdf.

53 United Nations. (2020). The Impact of COVID-19 on South-East Asia. Policy Briefs, 1-29.

${ }^{54}$ Article 2.1 of The International Covenant on Economic, Social and Cultural Rights (ICESCR).

55 Article 44.1 of the WHO International Health Regulation, https://www.who.int/ihr/publications/ 9789241580496/en/.

56 Nigam, Shalu. (2021). Ensuring Vaccine Equity, Erasing Vaccine Nationalism: Upholding the Human Rights and Justice Framework (April 15, 2021). Available at SSRN: https://ssrn.com/abstract=3827273 or http://dx.doi.org/10.2139/ssrn.3827273.
} 


\section{Conclusion}

In the name of human rights and Sustainable Development Goals, Covid-19 vaccination in Southeast Asia needs to be conducted equally. This is because the ASEAN has the potential to objectify, besides it is a regional organization that possesses robust cooperation. Furthermore, ASEAN cooperates with its partners such as ASEAN plus one and ASEAN plus three to carry out some research and produce Covid-19 vaccines. International law both hard and soft also requires inter-state cooperation, especially in facing the international nature of the pandemic.

\section{Acknowledgments}

The authors are grateful to Universitas Surabaya for the financial support provided.

\section{References}

ASEAN Biodaspora Virtual Center. (2021). Risk Assessment for International Dissemination of COVID-19 to the ASEAN Region (Vol. 2021). https://asean.org/storage/COVID-19 Report-of-ASEAN-BioDiaspora-RegionalVirtual-Center 26February2021.pdf

Bogdandy, A. von and P. A. V. (2020). The Role of International Law in Vaccinating Against Covid-19: Appraising the Covax Initiative (No. 2020-46; MPIL Research Paper Series).

Djalante, R., Nurhidayah, L., Minh, H. Van, Thi, N., Phuong, N., Mahendradhata, Y., Trias, A., Lassa, J., \& Ann, M. (2020). COVID-19 and ASEAN responses: Comparative policy analysis. Progress in Disaster Science, 8(January), 1-12. https://doi.org/http://dx.doi.org/10.1016/j.pdisas.2020.100129.

Forman, L., \& Kohler, J. C. (2020). Global health and human rights in the time of COVID19: Response, restrictions, and legitimacy. Journal of Human Rights, 19(5), 547556. https://doi.org/10.1080/14754835.2020.1818556.

FORUM-ASIA. (2020). Human Rights in Southeast Asia in Times of Pandemic. https://humanrightsinasean.info/wp-content/uploads/2020/09/LOCovidASIAF3.pdf.

Gavi. (2020). "Sustainable Development Goals". Available Online from: https://www.gavi.org/our-alliance/global-health-development/sustainabledevelopment-goals. [Accessed March 26, 2021]

Gostin, L. O., Karim, S. A., \& Mason Meier, B. (2020). Facilitating Access to a COVID-19 Vaccine through Global Health Law. Journal of Law, Medicine and Ethics, 48(3), 622-626. https://doi.org/10.1177/1073110520958892.

Human Rights Watch. (2020). "Whoever Finds the Vaccine Must Share It" Strengthening Human Rights and Transparency around Covid-19 Vaccines. Report, (October 2020). https://www.hrw.org/sites/default/files/media 2020/10/globalvaccine 1020 web.pdf. 
Institute for Human Rights and Business. (2020). Respecting Human Rights in the Time of the COVID-19 Pandemic: Examining Companies' Responsibilities for Workers and Affected Communities. at https://www.ihrb.org/focus-areas/covid-19/reportrespecting-.

Kaufman, R. E. (2011). Using Human Rights Mechanisms of the United Nations to Advance Economic Justice. Journal of Poverty Law and Policy, 1(6), 259-267.

Kilic T, Michler J. (2020). Socio-Economic Impacts of COVID-19 in Four African Countries: Watch the Event Recording. Available at: https://www.worldbank.org/en/ programs/Isms/brief/socioeconomic-impacts-of-covid-19-in-four-africancountries-watch-the-event-recording. [Accessed March 19, 2021]

Moon, S., Rottingen, J. A., \& Frenk, J. (2017). Global public goods for health: Weaknesses and opportunities in the global health system. Health Economics, Policy and Law, 12(2), 195-205. https://doi.org/10.1017/S1744133116000451.

Mukarram, M. (2020). Impact of COVID-19 on the UN Sustainable Development Goals (SDGs). Strategic Analysis, 44(3), 253-258. https://doi.org/10.1080/ 09700161.2020 .1788363$.

Nigam, Shalu. (2021). Ensuring Vaccine Equity, Erasing Vaccine Nationalism: Upholding the Human Rights and Justice Framework (April 15, 2021). Available at SSRN: https://ssrn.com/abstract=3827273 or http://dx.doi.org/10.2139/ssrn.3827273.

OECD. (2021). Access to COVID-19 vaccines: Global approaches in a global crisis. In OECD Policy Responses to Coronavirus (Issue March). https://www.oecd.org/coronavirus/ policy-responses/access-to-covid-19-vaccines-global-approaches-in-a-globalcrisis-c6a18370/.

OECD. (2021). Coronavirus (COVID-19) vaccines for developing countries: An equal shot at recovery. In OECD Policy Responses to Coronavirus (Issue February). https://www.oecd.org/coronavirus/policy-responses/coronavirus-covid-19vaccines-for-developing-countries-an-equal-shot-at-recovery6b0771e6/\#blocknotes-d7e2077.

Rahayu, S., \& Sulistiadi, W. (2020). The Effectiveness of COVID-19 Countermeasure Policy Implementation in Seven ASEAN Countries. Journal of Indonesian Health Policy and Administration, 5(2), 43-49. https://doi.org/10.7454/ihpa.v5i2.3880.

Saunders, J. (2020). Covid-19 and Human Rights. Oxfam Discussion Paper. 1-48.

Seshaiyer, P., \& McNeely, C. L. (2020). Challenges and Opportunities From COVID-19 for Global Sustainable Development. World Medical and Health Policy, 12(4), 443-453. https://doi.org/10.1002/wmh3.380.

Strangio, Sebastian. (2021). Southeast Asia COVID-19 Vaccine Coverage a Long Way Off: Report, Available Online from: https://thediplomat.com/2021/01/southeast-asiacovid-19-vaccine-coverage-a-long-way-off-report/. [Accessed March 20, 2021]

Sumner, A., Hoy, C., \& Ortiz-Juarez, E. (2020). Estimates of the impact of COVID-19 on global poverty. UNU WIDER Working Paper 2020/43, April, 1-9. https://doi.org/10.35188/UNU-WIDER/2020/800-9.

Terzakis, K., \& Maren Klein. (2021). SDG 17: Partnerships for the Goals. Policy Brief. 1-8. 
UNDP. (2020). Impact of COVID-19 on the Sustainable Development Goals: Pursuing the SDGs in a World Reshaped by COVID-19. https://sdgintegration.undp.org/ sites/default/files/Impact of COVID-19 on the SDGs.pdf.

United Nations Human Rights. (2020). Human Rights and Access to Covid-19 Vaccines. In Human Rights at The Heart of Response. Nomos Verlagsgesellschaft mbH \& Co. KG. https://doi.org/10.5771/9783845273945.

United Nations. (2020). The Impact of COVID-19 on South-East Asia. Policy Briefs, 1-29.

World Health Organization, World Trade Organization and World Intellectual Property Organization. (2020). Promoting Access to Medical Technologies and Innovation (2nd ed.). WHO, WTO and WIPO. https://doi.org/10.30875/fa323700-en.

Wouters, O. J., Shadlen, K. C., Salcher-konrad, M., Pollard, A. J., Larson, H. J., Teerawattananon, Y., \& Jit, M. (2021). Health Policy Challenges in ensuring global access to COVID-19 vaccines: production, affordability, allocation, and deployment.

The Lancet, 397(10278), 1023-1034. https://doi.org/10.1016/S01406736(21)00306-8.

Zen, F., Komazawa, O., Gross, J., Menon, J., Zen, F., Komazawa, O., \& Gross, J. (2019). Leave No One Behind. In Kimura, F., V. Anbumozhi, H. Nishimura. (eds.). Transforming and Deepening the ASEAN Community (Issue May, pp. 147-162). Jakarta: ERIA.

Conflict of Interest Statement: The author(s) declares that the research was conducted in the absence of any commercial or financial relationship that could be construed as a potential conflict of interest.

Copyright: (C) HALREV. This is an open access article distributed under the terms of the Creative Commons Attribution 4.0 International License (CC-BY 4.0), which permits unrestricted use, distribution, and reproduction in any medium, provided the original author and source are credited.

Hasanuddin Law Review (Hasanuddin Law Rev. - HALREV) is an open access and peer-reviewed journal published by Faculty of Law, Hasanuddin University, Indonesia. 